\begin{tabular}{l|c|c|c|}
\hline \hline & International Journal of Current Research in \\
\hline & Biosciences and Plant Biology \\
\hline EXCELLENT \\
PUBLISHERS
\end{tabular}

\title{
Preliminary study on morphological diversity of cowpea accessions [Vigna unguiculata (L.) Walp.] collected in the North of Côte d'Ivoire
}

\section{ASSOUMAN Jean Simon Konan (iD*, DIARRASSOUBA Nafan, YAO Saraka Didier Martial}

\author{
Unité de Formation et de Recherche (UFR) des Sciences Biologiques, Université Peleforo Gon Coulibaly (UPGC), \\ BP 1328 Korhogo, Côte d'Ivoire
}

*Corresponding author; e-mail: assoumanjeansimon@gmail.com

\begin{tabular}{ll}
\hline Article Info & Abstract \\
\hline Keywords: & $\begin{array}{l}\text { The collection and characterization of the diversity of local cowling ecotypes is an important lever in } \\
\text { defining the species' strategies for varietal improvement. The purpose of this study was to generate }\end{array}$ \\
$\begin{array}{l}\text { Cowpea } \\
\text { Diversity }\end{array}$ & $\begin{array}{l}\text { information on the diversity of cowpea [Vigna unguiculata (L.) Walp.] cultivars in the savannah area } \\
\text { Morphotypes }\end{array}$ \\
& farmers and traders in nine departments in the north of Côte d'Ivoire. These missions brought together \\
& 48 local cowpea ecotypes in seed form. These accessions were characterized on the basis of eight \\
& morphological characters, including two quantitative characters (weight of 100 seeds and length of \\
& seeds) and six qualitative characters (color, shape, presence of stain, appearance, eye shape and color \\
& around the hilum of seed). Overall, the results showed considerable variability in seed coat coloration \\
& in varying proportions. Overall, 35.42\% of the samples collected were white, 33.33\% were red and \\
& 31.25\% were other colors. The Multiple Correspondence analysis carried out using all the qualitative \\
& characters made it possible to group the 48 accessions collected into 16 morphological groups or \\
& morphotypes with distinct characteristics. In addition, they reflect a good part of the morphological \\
diversity of cowpea accessions from the north of Côte d'Ivoire that could be exploited in varietal \\
selection programs for the species.
\end{tabular}

- Received: 24 June 2021 • Revised: 15 August 2021 • Accepted: 25 August 2021 • Published Online: 6 September 2021

\section{Introduction}

Cowpea is one of the major legumes grown and consumed in the tropics and subtropics of Africa, Asia, Europe, and the Americas (Taffouo et al., 2008). Worldwide, an estimated 6.4 million tons of cowpea [Vigna unguiculata (L.) Walp.] are produced annually on approximately 12.7 million hectares (FAOSTAT, 2013). Sub-Saharan Africa accounts for about $95 \%$ of global cowpea production, with over $80 \%$ of Africa's share produced in West Africa (Nteranya and David, 2015). Due to its high protein (19-25\%), carbohydrates and mineral content in seeds, the cowpea plays an important role in human nutrition and the fight against malnutrition (Stoilova and Pereira, 2013). Seeds, fresh pods and cowpea leaves are consumed in many African countries. Leaves or tops are also used in livestock feeding (Abebe et al., 2005). Due to its ability to symbiotically fix atmospheric nitrogen, the insertion of the cowpea into crop rotations allows the nitrogen 
fertilizer requirements of subsequent crops on the same plot (Carsky et al., 2020; Tarawali et al., 2002; Sanginga et al., 2003).

In Côte d'Ivoire, although much consumed, cowpeas remain a marginal culture. Production is around 36.310 tons/year, representing less than $2 \%$ of African production (FAOSTAT, 2016). The lack of regular monitoring of cowpeas does not allow for an idea of the varieties grown and the performance obtained (Bio, 2002). In Côte d'Ivoire, studies on cowpeas have been carried out on the growth and health characteristics of some improved varieties (N'gbesso et al., 2013a), components of yield of improved varieties (N'gbesso et al., 2013b) and the agronomic and biochemical quality of some varieties (Boyé et al., 2016). However, none of these studies focused on the morphological diversity of existing cowpea cultivars in village lands. Whereas, for variety selection programs, knowledge of the diversity of traditional varieties and their evaluation are necessary (Hedge and Mishra, 2009; Doumbia et al., 2013). The objective of this study is to provide information on the variety of cowpeas grown in the savannah district for the management and improvement of the genetic resources of cowpeas in Côte d'Ivoire.

\section{Materials and methods}

\section{Study area}

The study was carried out in the savannah zone in the north of Côte d'Ivoire, between $9^{\circ} 25^{\prime \prime}$ Latitude North and $5^{\circ} 37^{\prime \prime}$ of Longitude West, at altitudes between 300 $\mathrm{m}$ and $400 \mathrm{~m}$. The collection was carried out in three administrative regions of Poro (Korhogo, Sinementiali and Dikodougou), Tchologo (Ferké, Ouangolo and Kong) and Bagoué (Boundiali, Kouto and Tengréla) (Fig. 1).

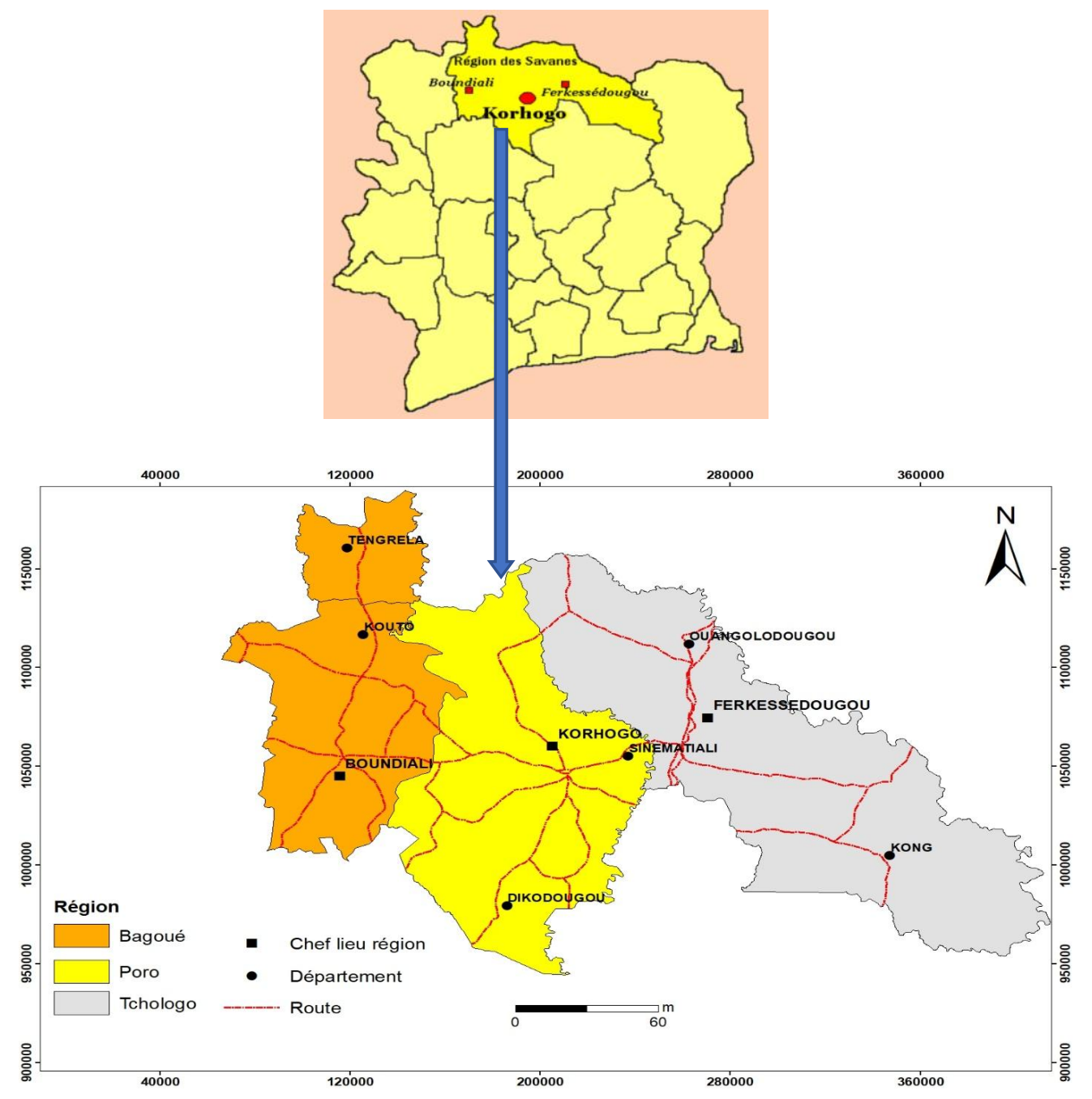

Fig 1: Map showing cowpea accessions collection sites. 


\section{Plant material}

The plant material was composed of local cowpea cultivars collected in the form of sheaths coded according to the origin and introduced under accession numbers in a collection created for this purpose at the University Peleforo GON COULIBALY (UPGC) of Côte d'Ivoire.

\section{Collection of accessions and measurement of cowpea morphological traits}

In each of the localities studied, the collection points were selected according to transects ranging from the region's administrative center and oriented in the four cardinal directions (North, South, East and West) according to Diarrassouba et al. (2008). On each axis, the sampling interval was set at $10 \mathrm{~km}$ as recommended by Diarrassouba et al. (2009). In each village within this interval, local samples of cowpeas were collected from the farmers.

A total of 48 accessions were collected as follows: 19 in the Bagoué region (Boundiali, Kouto, and Tengrela departments), 11 in the Tchologo (Ferkességougou, Ouangolodougou, and Kong), and 18 in the Poro region (Korhogo, Dikodougou, and Sinématiali). The accessions collected as seeds were transported to UPGC where they were washed and then dried during three days of sunlight between 8 am and 4 pm to homogenize the drying of all seed lots. The dried seed lots were treated with a paradichlorobenzene pesticide to prevent possible insect attacks of stored commodities and to reduce the risk of loss of viability of the stored seeds. Seeds from the treated accessions were stored in the UPGC gene bank at $25^{\circ} \mathrm{C}$ before the quantitative and qualitative characteristics were assessed.

Quantitative traits such as seed length and weight were assessed in the laboratory on a sample of 100 seeds by accession. Seed length (SL) was measured using a slide stand and the weight of 100 seeds (W100S) was measured using a precision digital balance of $0.01 \mathrm{~g}$. Qualitative traits were described in accordance with the terms reported by the cowpea descriptor (IBPGR, 1983). The qualitative characteristics related to the seed are the color, shape, stain presence, appearance, eye shape and color around the hilum of the seed.

\section{Data analysis}

The data collected were subjected to different methods of statistical analysis. For both quantitative traits, Pearson's correlation between 100 seed weight (W100S) and seed length (SL) was evaluated using STATISTICA version 7.1 software. Based on the relationship between $\mathrm{W} 100 \mathrm{~S}$ and SL, the qualitative variable describing seed size was selected to represent the two quantitative traits studied. The seed size variable was subdivided into three modalities that are small seeds (SL $<7 \mathrm{~mm})$, medium seeds $(7 \mathrm{~mm}-8 \mathrm{~mm})$ and large seeds (SL > $8 \mathrm{~mm}$ ).

For qualitative characters, the relative frequencies (pi) of appearance of the different modalities were calculated from the expression:

$$
p i=\frac{N i}{N} \times 100
$$

With Ni: the observed strength of the fourth modality for a given descriptor. $\mathrm{N}$ : the total number of individuals. To test the equiprobability of the appearance of the modalities of a given qualitative character, a Chi ${ }^{2}$ test was performed at the significance threshold of 0.05 (Yao et al., 2015). These relative frequencies allowed knowing the mode (most frequent or abundant phenotype) of the different qualitative characters used. For each qualitative character, the diversity indices of Shannon Weaver (H') and Simpson (D) were calculated using the following formulas proposed by Yao et al. (2020) and Gray et al. (1992):

$$
\begin{gathered}
H^{\prime}=\frac{-\sum_{i}^{n}\left(P_{i}\right) \times \ln \left(P_{i}\right)}{\ln (n)} \\
\boldsymbol{D}^{\prime}=\sum_{i}^{n}\{[\boldsymbol{n i}(\boldsymbol{n i}-\mathbf{1})] / N(N-\mathbf{1})\}
\end{gathered}
$$

With $\mathrm{n}$, the number of modalities of a character, when $\mathrm{H}$ ' tends to 1 , the diversity of the character is high. When $\mathrm{D}$ tends to 0 , the probability that two randomly drawn accessions in the study group of cowpea accessions have the same phenotype for a given trait is low, in other words, character variability is high (Yao et al., 2020).

Multiple Correspondence Analysis (MCA) was conducted using IBM's Statistical Package of Social Sciences (SPSS) Version 22.0 (IBM corp. Armonk, New York, USA) to highlight the links between accessions and different characters. The Hierarchical Ascending Classification (HAC) was realized using the 
XLSTAT software version 2016 based on the Jaccard's dissimilarity index to structure the different accessions. It allowed grouping the accessions studied according to their degree of similarity.

\section{Results}

\section{Variability of cowpea seeds according quantitative traits}

A positive and highly significant correlation at the threshold of 0.05 (Fig. 2) was observed between the weight of 100 seeds (W100S) and seed length $(\mathrm{r}=+0.927 ; \mathrm{p}<0.001)$. The weight of 100 seeds knowing seed size can be predicted with an accuracy of $86 \%$. Thus, the longer the seeds, the higher the weight.

The length of the seed transformed into a qualitative variable "seed size" has the three small, medium and large seed modalities that weighed $9.41 \pm 0.66 \mathrm{~g}$, $11.65 \pm 0.95 \mathrm{~g}$ and $15.68 \pm 2.50 \mathrm{~g}$, respectively. The differences observed between the seed masses expressed by the three seed size modalities were significant $(\mathrm{F}=85.99 ; \mathrm{p}<0.001)($ Table 1$)$.

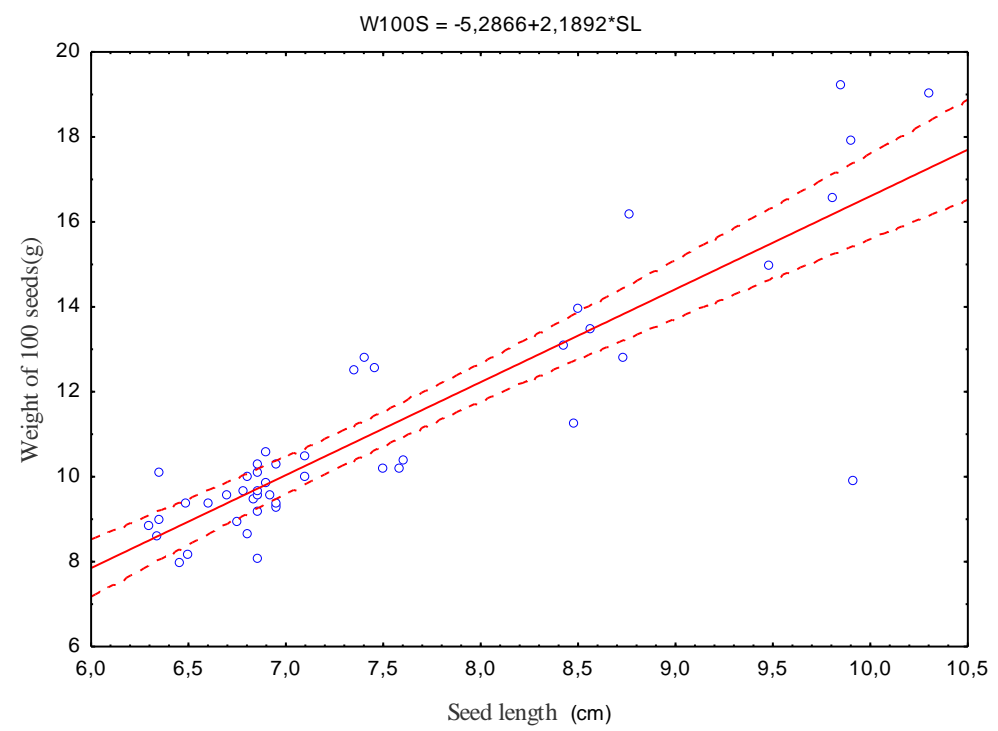

Fig 2: Correlation between weight of 100 seeds and seed length.

\section{Variability of qualitative traits related to cowpea seed}

The modalities of each of the seven seed-related qualitative traits significantly $(\mathrm{p}<0.001)$ differed from the cowpea accessions collected in northern Côte d'Ivoire.

Seed size: The majority of the collected accessions i.e., $60.42 \%$ showed small seeds. $16.67 \%$ showed medium size seeds and $22.92 \%$ showed large seeds $(\chi 2=16.125$; $\mathrm{p}<0.001)$ (Table 1).

Seed color: Eight different seed colors have been identified and appear at unequal frequencies $\left(\chi^{2}=\right.$ 51.333; $\mathrm{p}<0.001)$. White and light red seeds predominated with frequencies of $35.42 \%$ and $33.33 \%$, respectively. Five accessions of the collection, i.e., $10.42 \%$, are ochre colored. The dark-red color represents $8.33 \%$ and the dark-brown and ash-gray colors, each representing $4.17 \%$, are weakly represented. Finally, black and red-ochre seed accessions are rare and each account for $2.08 \%$ of the harvested accessions (Table 2).

\section{Shape of seed}

The $\mathrm{Chi}^{2}$ test $\left(\chi^{2}\right)$ was highly significant $\left(\chi^{2}=14.083\right.$; $\mathrm{p}<0.001)$ to differentiate accessions according to seed shape. The study showed that $60.42 \%$ of the accessions of cowpeas originating in the savannah district had ovoid-shaped seeds, $22.92 \%$ of accessions had kidneyshaped seeds, $10.42 \%$ of the accessions had rhomboid seeds, and only $6.25 \%$ of accessions had globular seeds (Table 2).

Seed eye shape trait: Accessions with small-eyed seeds were in the majority $(77.08 \%)$ in contrast to large-eyed 
accessions that were in the minority $(22.92 \%) ;(\chi 2=$ 14.083; $\mathrm{p}<0.001)($ Table 2).

Appearance of seed coat: The seed coat aspect of cowpea accessions is unevenly distributed $(\chi 2=14.083$; $\mathrm{p}<0.001)$. Smooth seed accessions $(77.08 \%)$ were more abundant within the collection than wrinkled seed accessions (22.92\%), (Table 2).
Stain on the seed coat: Only $10.42 \%$ of the accessions had seeds with spots on the seed coat while $89.58 \%$ did $\operatorname{not}(\chi 2=30.083 ; \mathrm{p}<0.001)($ Table 2$)$.

Color around the eye: Nearly all of the cowpea accessions encountered (97.92\%) in northern Côte d'Ivoire are non-colored around the eye and only $2.08 \%$ are colored around the eye $(2=44.083 ; \mathrm{p}<0.001)$ (Table 2$)$.

Table 1. Expression of the weight of cowpeas according to the modalities of the variable transformed seed size into a qualitative variable.

\begin{tabular}{|c|c|c|c|c|c|}
\hline \multirow{2}{*}{ Seed length } & \multicolumn{3}{|c|}{ Weight of 100 seeds $(\mathrm{g})$} & \multirow{2}{*}{$\mathbf{F}$} & \multirow{2}{*}{ p-value } \\
\hline & Minimum & Maximum & Mean & & \\
\hline Small seeds & 8.00 & 10.60 & $9.41 \pm 0.66$ & & \\
\hline Medium seeds & 10.40 & 12.80 & $11.65 \pm 0.95$ & 85.99 & $<0.001$ \\
\hline Large seeds & 12.80 & 19.25 & $15.68 \pm 2.50$ & & \\
\hline
\end{tabular}

Table 2. Local cowpea varietal diversity by seed qualitative traits.

\begin{tabular}{|c|c|c|c|c|c|c|c|}
\hline $\begin{array}{l}\text { Qualitative } \\
\text { characters }\end{array}$ & Modalities & Numbers & Frequency $(\%)$ & $\operatorname{Chi}^{2}\left(\chi^{2}\right)$ & $\mathbf{p}$ & H' & D \\
\hline \multirow[t]{3}{*}{ SL } & Small $(<7 \mathrm{~mm})$ & 29 & 60.42 & 16.125 & $<0.001$ & 0.860 & 0.432 \\
\hline & Medium (7 mm - $8 \mathrm{~mm})$ & 8 & 16.67 & & & & \\
\hline & Large $(>8 \mathrm{~mm})$ & 11 & 22.92 & & & & \\
\hline \multirow[t]{8}{*}{$\mathrm{SC}$} & White & 17 & 35.42 & 51.333 & $<0.001$ & 0.742 & 0.268 \\
\hline & Ochre & 5 & 10.42 & & & & \\
\hline & Ochre-red & 1 & 2.08 & & & & \\
\hline & Light red & 16 & 33.33 & & & & \\
\hline & Dark red & 4 & 8.33 & & & & \\
\hline & Dark brown & 2 & 4.17 & & & & \\
\hline & Ash-grey & 2 & 4.17 & & & & \\
\hline & Black & 1 & 2.08 & & & & \\
\hline \multirow[t]{4}{*}{ SS } & ovoid & 30 & 60.50 & 35.000 & $<0.001$ & 0.743 & 0.437 \\
\hline & Globular & 3 & 6.25 & & & & \\
\hline & Reniform & 10 & 20.83 & & & & \\
\hline & Rhomboid & 5 & 10.42 & & & & \\
\hline \multirow[t]{2}{*}{ ES } & Small & 37 & 77.08 & 14.083 & $<0.001$ & 0.776 & 0.639 \\
\hline & Large & 11 & 22.92 & & & & \\
\hline \multirow[t]{2}{*}{ SEC } & Absence & 47 & 97.92 & 44.083 & $<0.001$ & 0.146 & 0.958 \\
\hline & Presence & 1 & 2.08 & & & & \\
\hline \multirow[t]{2}{*}{ SA } & Smooth & 37 & 77.08 & 14.083 & $<0.001$ & 0.783 & 0.663 \\
\hline & Wrinkled & 11 & 22.92 & & & & \\
\hline \multirow[t]{2}{*}{ SSC } & Absence & 43 & 89.58 & 30.083 & $<0.001$ & 0.599 & 0.746 \\
\hline & Presence & 5 & 10.42 & & & & \\
\hline
\end{tabular}

SC: seed color; SL: seed length; SS: seed shape; SSC: stain on seed coat; SA: seed appearance; SEC: seed eye color; ES: eye shape; H': normalized Shannon-Weaver diversity index; D: Simpson index; $\chi^{2}:$ Chi $^{2}$ test value; p: probability value associated with the $\chi^{2}$ test.

For seed-related qualitative traits, Shannon-Wiener indices $\left(\mathrm{H}^{\prime}\right)$ were generally greater than 0.5 with the exception of the color around the eye, which has a very low index $\left(H^{\prime}=0.146\right)$. The Simpson index ranged from 0.268 to 0.958 , with only seed color traits $(\mathrm{D}=0.268)$, seed shape $(D=0.437)$ and seed size $(D=0.432)$ showing indices of less than 0.5 .

\section{Variability structure of cowpea accessions based on qualitative seed traits}

The ACM made it possible to analyze all the qualitative variables making it possible to observe proximity between variable modalities and between accessions. The first two factorial axes explain $94.24 \%$ of the total 
variability, of which $65.03 \%$ for the first axis and $29.25 \%$ for the second axis. According to analyzes of the symmetrical graph of the various modalities studied, axis 1 pits large seeds against large eyes characterized by a wrinkled and reniform appearance against small, smooth, small-eyed seeds.

Axis 2 contrasts medium-sized rhomboid-shaped seeds with or without stains on the seed coat with small globular or ovoid seeds with no stains on the seed coat (Fig. 3 and Fig. 4). The projection of the 48 accessions in the factorial plane defined by axes 1 and 2 highlights 3 morphological groups. Group 1 is characterized by accessions with large white seeds, wrinkles, kidney shape and large eye. Group 2 includes accessions with smooth seeds, ovoid or globular. Group 3 presents the medium-sized, rhomboid-shaped accessions with or without stain on the seed coat.

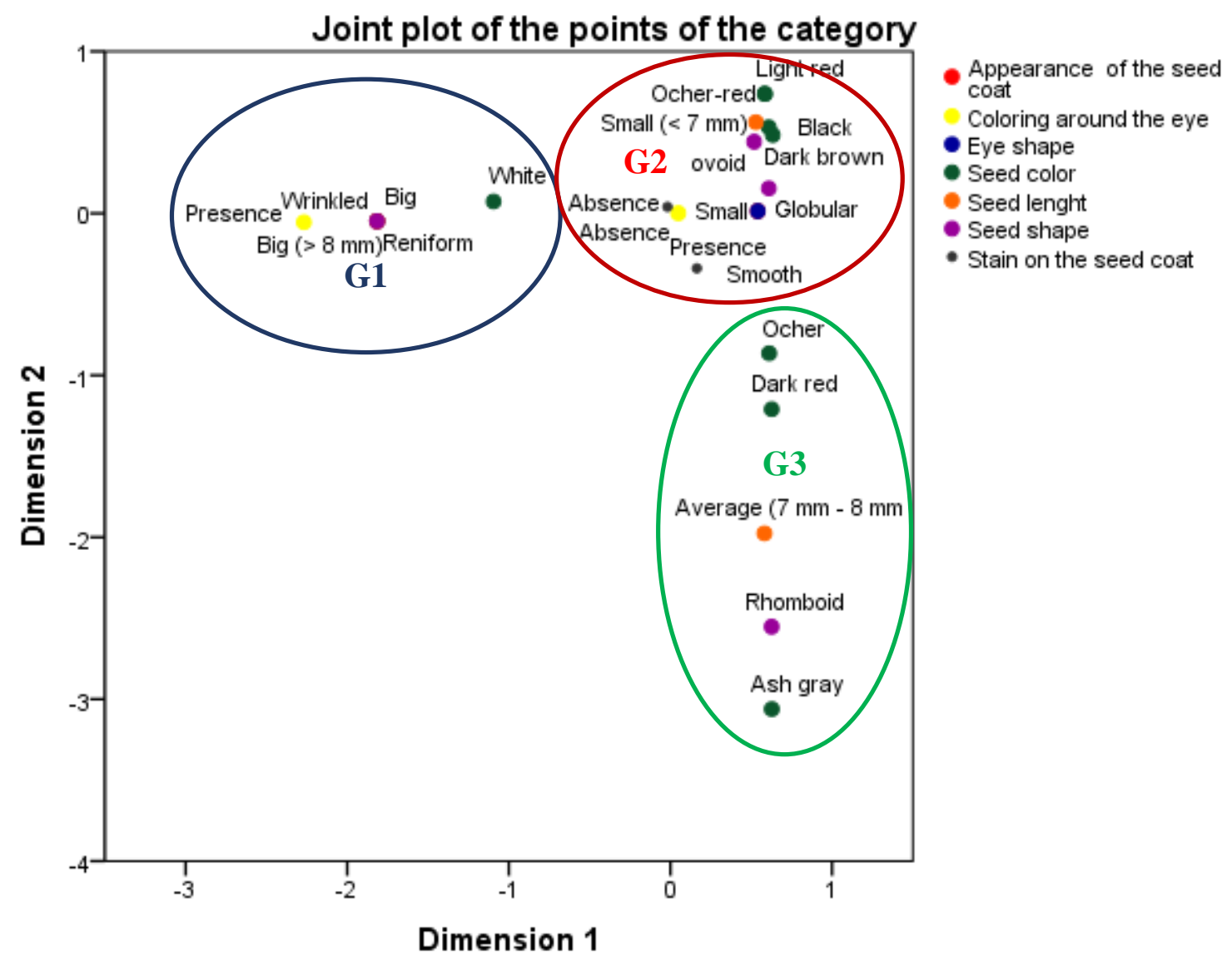

Fig 3: Multiple correspondent analysis of cowpea accessions harvested in North Côte d'Ivoire.

Observations from the MCA were confirmed by analysis of the Hierarchical Ascending Classification (HAC), which was used to construct a dendrogram from the Jaccard dissimilarity index, which grouped the 48 accessions studied according to their degree of morphological resemblance (Fig. 5). The dendrogram generated 16 distinct morphological or morphological units from the 48 accessions. At the truncation of an average link of 0.6 , the 16 morphological units are also classified into 3 groups. These 3 groups have the same characteristics as those generated by the MCA.
Group 1 is characterized by large-seed accessions of white color, wrinkled appearance, of kidney shape and large eye. This group consists of three morphological units M1, M2 and M3 (Fig. 6):

- The M1 morphological unit is characterized by the presence of tasks on the tegument. This unit contains a single accession (NTK01).

- Morphotype M2 differs from other accessions of the group by a brown color around the eye of the seed. Only one accession represents this morphotype (NTE04) 


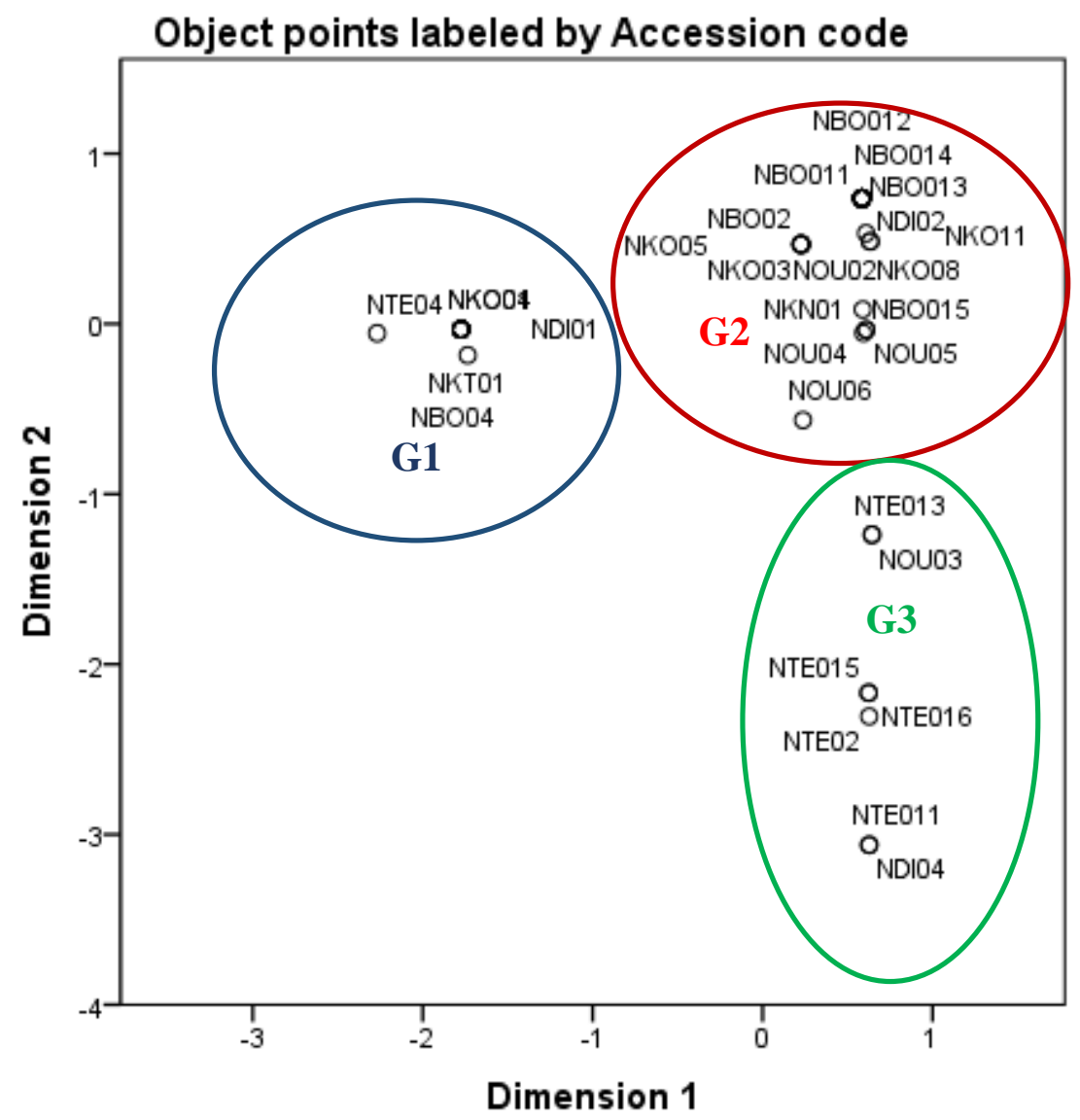

Fig 4: Projection of the 48 accessions in the dimensional plane 1 and 2 from the MCA.

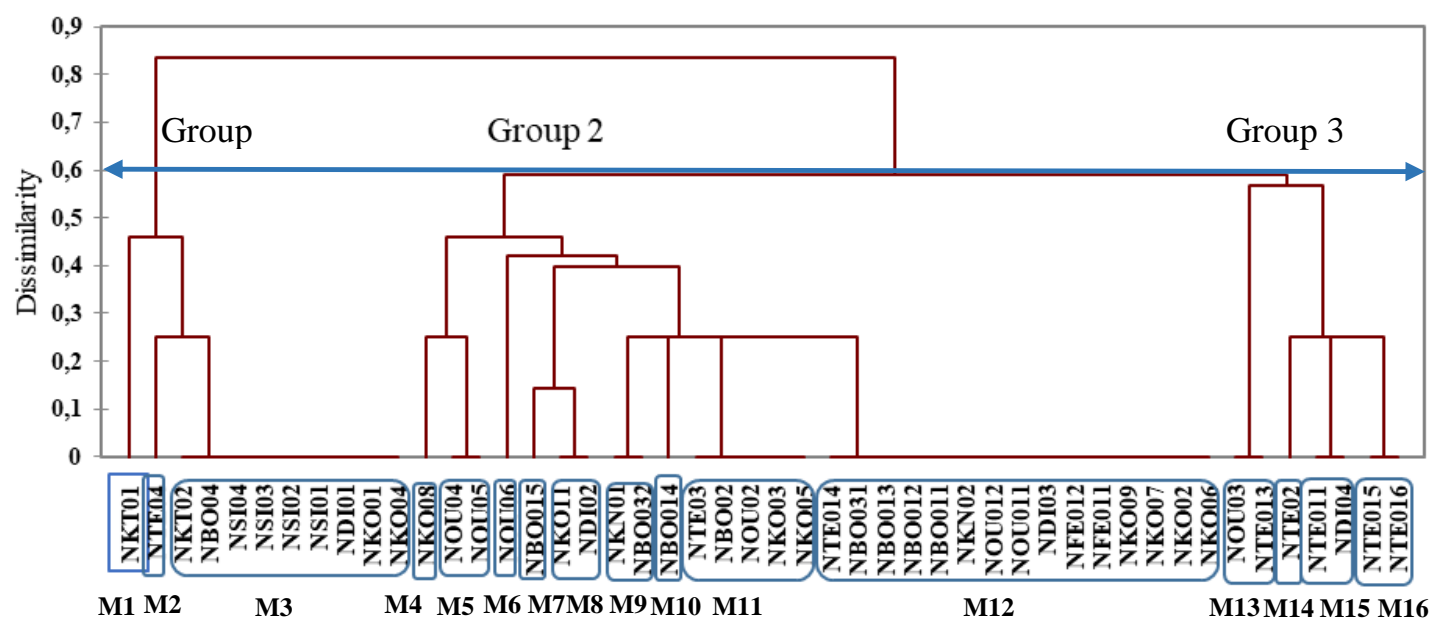

Fig 5: Collected accessions hierarchical ascending classification.

- The M3 morphotype with 9 accessions (NKT09, NBO04, NSI04, NSI03, NSI02, NSI01, NKO01, NKO04) has no staining around the hilum and no staining on the tegument.

- Group 2 generally includes accessions with small smooth seeds, small eye and ovoid or globular shape. It includes the M4 to M12 morphotypes:
- The M4 unit contains seeds of black color and globular shape. This morphotype is represented by a single accession in our collection (NKO08)

- Morphotype M5 has ochre-colored seeds and also globular seeds. Two accessions (NOU04, NOU05) represent this morphotype. 

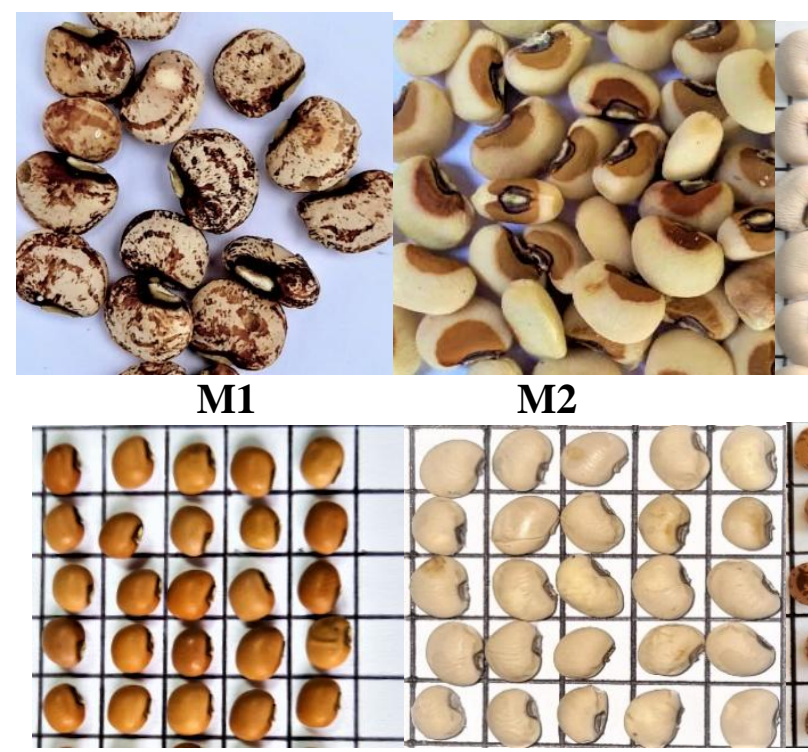

M2

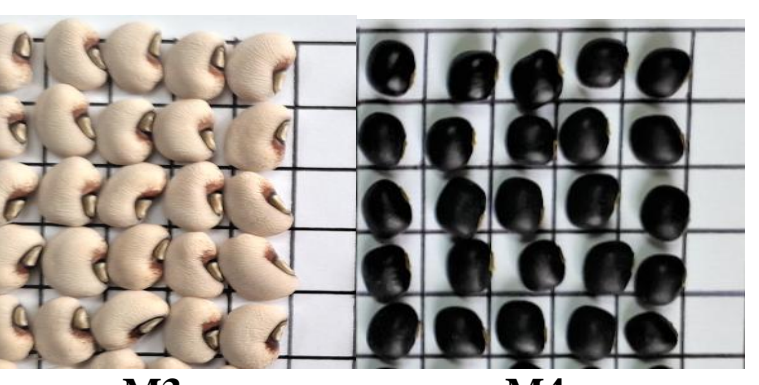

M3

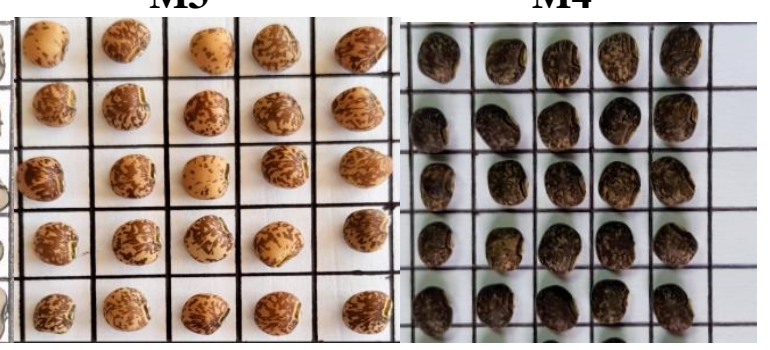

M5

M6

M7

M8

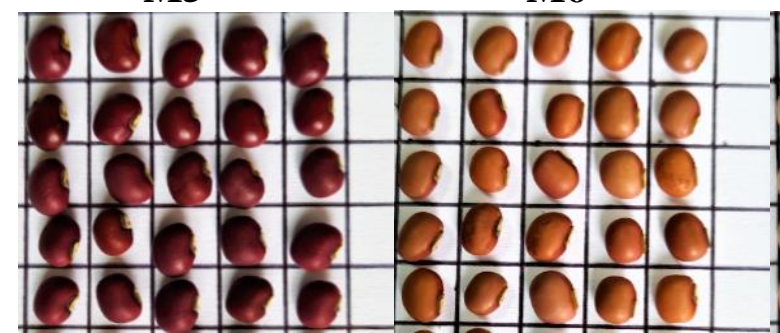

M9

M10

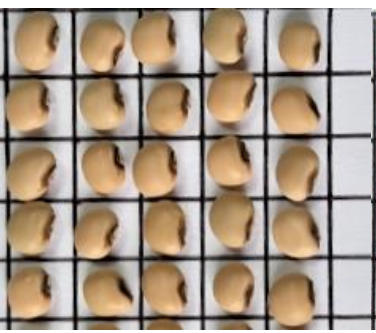

M11

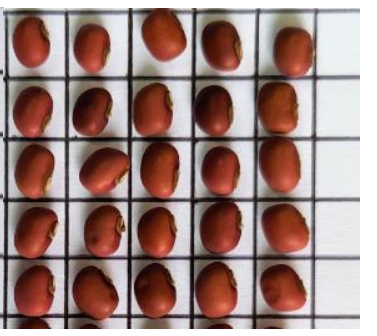

M12

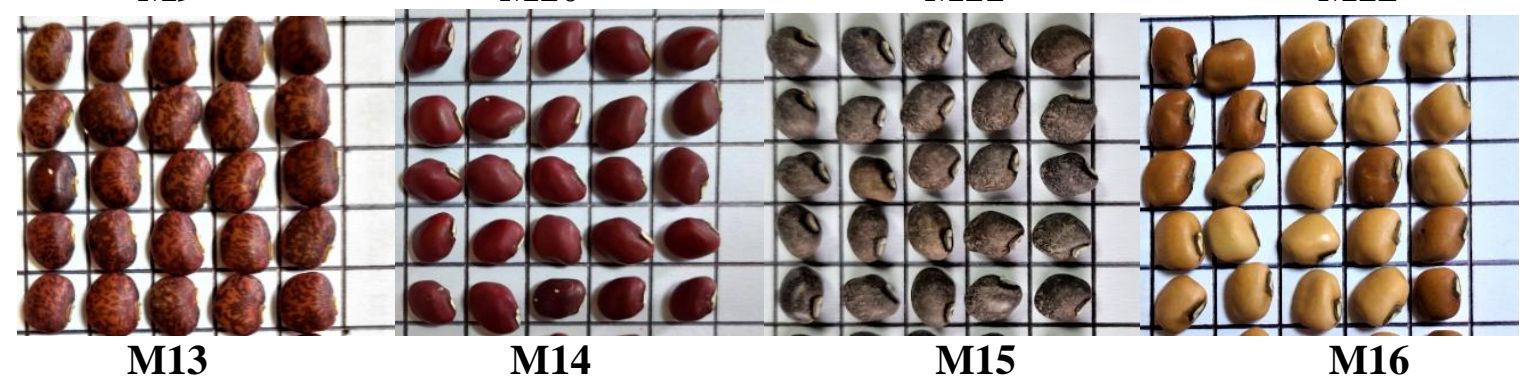

Fig 6: Different cowpea morphotypes collected in the savanna district of northern Côte d'Ivoire. M1: Seed's white, wrinkled, kidney-shaped seeds, large size presence of stains on the tegument; M2: Seed's white, wrinkled, kidney, large size presence of coloring around the eye; M3: Seed's white, wrinkled, kidney, large size seeds; M4: White seeds, wrinkles, kidney-shaped, presence of stains on the tegument; M5: Ochre seeds, smooth, globular, small size; M6: White, smooth, ovoid, medium size; M7: White, smooth, ovoid seeds, small size, presence of stains on the tegument; M8: Brown-dark, smooth, ovoid seeds, small size, stains on the integument; M9: Dark-red, ovoid, smooth, small seed; M10: Ochre, ovoid, smooth, small-sized seeds; M11: White, ovoid, smooth, small-sized seeds; M12: Light-red, ovoid, smooth, small-sized seeds; M13: Dark-red, smooth, ovoid seeds, stains on the seed coat; M14: Dark red, smooth, rhomboid, medium size; M15: Ash-gray, smooth, rhomboid, medium size, stains on the tegument; M16: Ochre seeds, rhomboid, medium size.

- Morphotype M6 has medium-sized, ovoid-shaped white seeds. The collection presented a single accession for this morphotype (NOU06)

- The M7 morphological unit contains small ochrecolored ovoid seeds and stains on the coat. Only one accession (NBO015) represents this morphotype in our collection.
- Morphotype M8 differs from morphological unit M7 in its dark brown color of the seeds. This morphotype is also represented by two accessions (NKO011, NDDI02)

- Morphotype M9 has dark red colored seeds. Two accessions represent this morphotype (NKN01, NBO032) 
- The seeds of the morphological unit M10 are of ochre-red color. This morphotype is represented by a single accession in our collection (NBO014)

- The M11 unit has white colored seeds. Five accessions were identified in the collection (NTE03, NBO02, NOU02, NKO03, NKO05)

- Morphotype M12 contains light-red accessions. This morphotype is represented by 15 accessions (NTE014, NBO031, NBO013, NBO012, NBO011, NKN02, NOU012, NOU011, NDI03, NFE00 12, NFE011, NKO09, NKO07, NKO02, NKO06).

- Group 3 includes morphological units from M13 to M16. All seeds in this group are medium in size. It usually includes seeds of rhomboid or ovoid shape, with presence or absence of stain on the coat.

- The M13 morphotype seeds are dark red colored with stains on the tegument. It is represented by two accessions (NOU03, NTE013).
- The morphological unit M14 has its seeds which are dark red colored and rhomboid shaped. Only one accession represents this morphotype (NTE02).

- Seeds in the morphological unit M15 are of ashgray color and have stains on the coat. They are rhomboid in shape. Two accessions also represent these morphotypes (NTE011, NDI04)

- The M16 unit contains accessions with ochrecolored seeds, without staining on the tegument and rhomboid shape. Two accessions were recorded for this morphotype (NTE015, NTE016).

- The frequency of the different morphotypes obtained varied significantly $\left(\chi^{2}=72,667 ; p<\right.$ 0.001). Morphotype M12 accessions (31.25\%) and M3 accessions (18.75\%) are the largest in the collection (Table 3).

Table 3: Numbers of the different cowpea morphotypes collected in the savannah district.

\begin{tabular}{|c|c|c|c|c|c|c|}
\hline Group & Description & Morphotypes & Numbers & Percentage (\%) & $\operatorname{Chi}^{2}\left(\chi^{2}\right)$ & P value \\
\hline \multirow{3}{*}{ I } & \multirow{3}{*}{$\begin{array}{l}\text { white color, wrinkled appearance, } \\
\text { kidney-shaped, large }(>8 \mathrm{~mm}) \text { and } \\
\text { large eye }\end{array}$} & M1 & 1 & 2.08 & \multirow[t]{17}{*}{72.667} & \multirow[t]{17}{*}{$\mathrm{P}<0.001$} \\
\hline & & M2 & 1 & 2.08 & & \\
\hline & & M3 & 9 & 18.75 & & \\
\hline \multirow{9}{*}{ II } & \multirow{9}{*}{$\begin{array}{l}\text { Smooth appearance, small eye, } \\
\text { ovoid or globular shape and } \\
\text { mostly small }(<7 \mathrm{~mm})\end{array}$} & M4 & 1 & 2.08 & & \\
\hline & & M5 & 2 & 4.17 & & \\
\hline & & M6 & 1 & 2.08 & & \\
\hline & & M7 & 1 & 2.08 & & \\
\hline & & M8 & 2 & 4.17 & & \\
\hline & & M9 & 2 & 4.17 & & \\
\hline & & M10 & 1 & 2.08 & & \\
\hline & & M11 & 5 & 10.42 & & \\
\hline & & M12 & 15 & 31.25 & & \\
\hline \multirow{5}{*}{ III } & \multirow{5}{*}{$\begin{array}{l}\text { Smooth appearance, rhomboid } \\
\text { shape, medium size ( } 7 \text { to } 8 \mathrm{~mm} \text { ). } \\
\text { presence or absence of stain on the } \\
\text { integument }\end{array}$} & M13 & 2 & 4.17 & & \\
\hline & & M14 & 1 & 2.08 & & \\
\hline & & M15 & 2 & 4.17 & & \\
\hline & & M16 & 2 & 4.17 & & \\
\hline & & TOTAL & 48 & 100 & & \\
\hline
\end{tabular}

\section{Discussion}

Any rational use of the genetic diversity of a plant in an area requires a good prior knowledge of its diversity. This study assessed the current status of the diversity of cowpeas in the savannah district of northern Côte d'Ivoire. The positive and highly significant correlation between 100 seed weight and seed length demonstrated that seed length is a good indicator of seed weight. In this study, seed length was used to classify seeds into three groups: small $(\mathrm{SL}<7 \mathrm{~mm})$, medium $(7 \mathrm{~mm}-8$ $\mathrm{mm}$ ), and large (SL > $8 \mathrm{~mm}$ ). Doumbia et al. (2013) showed in their work that large varieties are interesting for consumers and often have good technological qualities. Seed size directly affects productivity and, together with seed color, determines the quality of seed for marketing (Lopes et al., 2003).

Analysis of qualitative characteristics such as seed color, seed appearance, seed shape, eye shape, tegument 
stain, and color around the eye showed great variability within the study collection. This large variability could result from the expression of high genotypic heterogeneity. Similar results were obtained by Djilé et al. (2016) in Cameroon.

Simpson's index ranging from 0 to 1 , as determined by the formulation proposed by Gray et al., 1992, yielded values below average ( 0.5$)$ for seed color, seed shape, and seed size. This reflects a great variability of accessions of these characters. These three traits could be important criteria for seed structuring in cowpea. For seed color, this index was particularly low in comparison to all other characters $(\mathrm{D}=0.268)$. It could therefore be said that the greatest variability in cowpea seeds is in the color of the coat. This wide variability was confirmed by studies of Gbaguidi et al. (2015) in Benin, Djilé et al. (2016) in Cameroon and Ghalmi (2011) in Algeria. However, in our study, seed coloration showed 7 variants, whereas Gbaguidi et al. (2015), Djilé et al. (2016) and Ghalmi (2011) found 8, 12 and 10 variants, respectively.

The results of the MCA and HAC were able to separate several well-differentiated morphotypes and bring together those that are identical or close. The Multiple Correspondence Analysis (MCA) compared broad and wrinkled seed morphotypes with smooth seed morphotypes. The Hierarchical Ascending Classification (HAC) groups the 48 accessions first into three classes at the truncation of an average link of 0.6 , then into 16 morphological or morphological units.

This implies that there are duplicates within the accessions collected. This situation could be explained by the fact that within a collection, the same variety can have several names, as was the case with yam (Loko et al., 2013) and fonio (Dansi et al., 2010). This characterization therefore made it possible to identify these duplicates and to establish equivalence between the varieties collected as Kuruma et al., (2008) in Kenya for the cowpea and Basu et al., (2007a and 2007b) in Botswana on voandzou.

The frequency of the different morphotypes varied significantly, indicating that M12 (small light red and smooth seeds) representing $31.25 \%$ of the collection and M3 (large white and wrinkled seeds) with $18.75 \%$ were the most abundant and M1, M2, M4, M6, M7, M7, M12 were the most abundant 10 and M14 with $2.08 \%$ each, are rare in the collection. This variability may be due to farmers' practices that take into account certain characteristics, especially seed color, seed appearance and seed size, as criteria for seed selection when planting crops (Ouédraogo et al., 2010).

These results corroborate those of N'Da et al. (2014), who argue that the mass selection carried out each year by farmers to renew the crop, favors this differentiation between the local maize cultivars collected in the center and center-west of Côte d'Ivoire. In addition, this diversity could be explained by the value or importance that cultivars represent to farmers in a given area.

In Côte d'Ivoire, white and red varieties are the most consumed (Bio, 2002), which would explain the abundance of M3 (large white and wrinkled seeds) and M12 (small light red and smooth seeds) morphotypes. Also, in the collection area of this study, the Senoufo people use the black-colored cowpea only for customary rituals, which would be the source of the rarity of certain morphotypes such as M4 (small black and smooth seeds).

Finally, the diversity of cowpea seeds would also come from the method of appropriation of seeds (exchange of varieties between producers in the same locality or another locality, etc.) and from the management and conservation of the seed stock (Konan et al., 2007 and N'Da et al., 2014). Indeed, Drinic et al. (2012) point out that the morphological differences between cultivars in the same or different localities are due to the adaptation of these cultivars to environmental conditions.

\section{Conclusions}

Analysis of the morphology of the cowpea seeds collected in the savannah district of Côte d'Ivoire shows the existence of the significant diversity of the cowpea cultivated in this area. Traits such as seed color, seed shape and seed size are the most important seed diversification criteria for cowpea cultivars. All the qualitative and quantitative characters used in this study made it possible to structure 48 accessions into 16 distinct morphological units or morphotypes present in the savannah district in Côte d'Ivoire, the most abundant of which is the morphotype M12 with a light red color, smooth and small in size. This study should be supplemented by that of agromorphological and then molecular descriptors to complete the work of characterizing diversity. In order to avoid genetic erosion, in situ and ex situ conservation of this diversity is necessary. 


\section{Conflict of interest statement}

Authors declare that they have no conflict of interest.

\section{Acknowledgement}

The author sincerely thanked Dr. KOKORE Angoua Baudouin for is help in the experience.

\section{References}

Abebe, G., Assefa, T., Harrun, H., Mesfine, T., AlTawaha A-R.M., 2005. Participatory selection of drought tolerant maize varieties using mother and baby methodology: a case study in the semiarid zones of the Central Rift Valley of Ethiopia. World J Agric Sci., 1(1): 22-27.

Basu, S., Mayes, S., Davey, M., Jeremy, A., Roberts, S.N., Azam-Ali, R.M., Remy, S., 2007a. Inheritance of 'domestication' traits in Bambara groundnut (Vigna subterranea (L.) Verdc). Euphytica, 157: 59-68.

Basu, S., Roberts, J.A.S., Azam-Ali, N.M., 2007b. Development of microsatellite markers for Bambara groundnut (Vigna subterranea L. Verdc.) an underutilized African legume crop species. Mol. Ecol. Notes, 7: 1326-1328.

Bio, G.S., 2002. Le marché du niébé dans les pays du Golfe de Guinée (Côte-d'Ivoire, Ghana, Togo, Bénin et Nigeria). [Online] Available: http://www.hubrural.org/IMG/pdf/pays_golfe_guine e_marche_niebe.pdf.

Boyé, M.A.D., Yapo, S.E.S., Koffi, N'd.B.C., Kouassi, N'd.J., Tonessia, D.C., Soko, D.F., Ballo, E.K., Seu, J.G., Ayolié, K., Kouadio, Y.J., 2016. Etude de la qualité agronomique et biochimique de quelques variétés de niébé (Vigna unguiculata (L.) Walp. (Fabaceae) provenant de la Côte d'Ivoire. Eur. Scient. J., 12: 362-375.

Carsky, R.J., Vanlauwe, B., Lyasse, O., 2002. Cowpea Rotation as a Resource Management Technology for Cereal- Based Systems in the Savannas of West Africa. In: Fatokun, C.A., Tarawali, S.A., Singh, B.B., Kormawa, P.M., Tamo, M. (Eds.), Challenges and Opportunities for Enhancing Sustainable Cowpea Production. International Institute of Tropical Agriculture: Ibadan, Nigeria. pp.252-266.

Dansi, A., Adoukonou-Sagbadja, H., Vodouhé, R., 2010. Diversity, conservation and related wild species of Fonio millet (Digitaria spp.) in the northwest of Benin. Genet. Resour. Crop Evol., 57:
827-839.

Diarrassouba, N., Fofana, I.J., Bakayoko, A., N'guessan, K.A., Sangare A., 2009. Influence des systèmes agraires sur la dynamique de régénération naturelle du karité : Vitellaria paradoxa Cf Gaernt (Sapotaceae) en Côte d'Ivoire. Agron. Afric., 21(1): 49-58.

Diarrassouba, N., Koffi, K.E., N'Guessan, K.A., Patrick, V., Sangaré, A., 2008. Connaissances locales et leur utilisation dans la gestion des parcs à karité en Côte d'Ivoire. Afrika Focus, 21(1): 77-96.

Djilé, B., Ousmane, B., Philippe, K., Ange, P.T.M., Ali M., 2016. Diversité agrogénétique des cultivars locaux de niébé (Vigna unguiculata) à l'extrêmenord du Cameroun. Int. J. Innov. Appl. Stud., 17(1): 255-268.

Doumbia, I.Z., Akromah, R., Asibuo, J.Y., 2013. Comparative study of cowpea germplasms diversity from Ghana and Mali using morphological characteristics. J. Plant Breed. Genet., 1(3): 139147.

Drinic, S.M., Andjelkovic, V., Micic, D.I., 2012. Genetic diversity of maize landraces as sources of favorable traits. In: Caliskan, M. (ed.) The molecular basis of plant genetic diversity. InTech, Rijeka, pp 89-112.

FAOSTAT, 2013. FAO Statistical Production. [Online] Available: www.faostat.org

FAOSTAT, 2016. FAO Statistical Production. [Online] Available: http://www.faostat3.org (02/03/2021).

Gbaguidi, A.A., Assogba, P., Dansi, M., Yedomonhan, H., Dansi, A., 2015. Caractérisation agromorphologique des variétés de niébé cultivées au Bénin. Int. J. Biol. Chem. Sci., 9(2): 1050-1066.

Ghalmi, N. 2011. Etude de la diversité génétique de quelques écotypes locaux de Vigna unguiculata (L.) Walp cultivés en Algérie. Ecole nationale supérieure agronomique (ENSEA). El harach-Alger. Thèse de Doctorat en sciences agronomiques. p.177.

Gray, J.S., McIntyre, A.D.,Stirn, J., 1992. Manuel des méthodes de recherche sur l'environnement aquatique. Onzième partie. Evaluation biologique de la pollution marine, eu égard en particulier au benthos. FAO Document technique sur les pêches, $\mathrm{N}^{\circ} 324$, p.53.

Hedge, S.V., Mishra, K.S., 2009. Landraces of cowpea, Vigna unguiculata (L.) Walp. As potential sources of genes for unique characters in breeding. Genetic Resources Crop Evolut., 56: 615-627.

IBPGR (International Board for Plant Genetic 
Resources), 1983. Descriptors for cowpea. IBPGR Secretariat, Rome.p30.

Konan, K.C., Roy-Macauley, H., Gueye, M.C., Otto, M.C., Rami, J.F., Pasquet, R.S., 2007. Diversité génétique des variétés traditionnelles de niébé [Vigna unguiculata (L.) Walp.] au Sénégal : étude préliminaire. Plant Genet. Resour., 152: 33-44.

Kuruma, R.W., Kiplagat, O., Ateka, E., Owuoche, G., 2008. Genetic diversity of Kenyan cowpea accessions based on morphological and microsatellite markers. East Afr. Agric. For. J., 76: 3-4.

Loko, Y.L., Dansi, A., Linsoussi, C., Tamo, M., Vodouhè, R., Akoegninou, A., Sanni, A., 2013. Current status and spatial analysis of Guinea yam Dioscorea cayenensis Lam. -D. rotundata Poir. complex diversity in Benin. Int. Res. J. Agric. Sci. Soil Sci., 3(7): 219-238.

Lopes, F.C., Gomes, R.L.F., Fiho. F.R.F, 2003. Genetic control of cowpea seed sizes. Scientia Agricola, 60(2): 315-318.

N'gbesso, F.P.M., Fondio, L., Dibi, K.B.E., Djidji, A.H., Kouamé, N.C., 2013a. Étude des composantes du rendement de six variétés améliorées de niébé [Vigna unguiculata (L.) Walp]. J. Appl. Biosci., 63: $4754-4762$.

N'gbesso, F.P.M., Zohouri, G.P., Fondio, L., Djidji A.H., Konate, D., 2013b. Etude des caractéristiques de croissance et de l'état sanitaire de six variétés améliorées de niébé [Vigna unguiculata (L.) Walp] en zone centre de Côte d'Ivoire. Int. J. Biol. Chem. Sci. 7(2), 457-467.

N'Da, H.A., Kouakou, K.C., Zoro, A.B., 2014. Diversité morphologique des variétés locales de maïs (Zea mays L.) collectées au centre et centre-Ouest de la Côte d'Ivoire. Eur. Scient. J., 10(12): 349-365.

Nteranya, S., David, B., 2015. Oléagineux et niébé. [Online] Available: https://www.afdb.org/fileadmin/ uploads/afdb/Documents/Events/DakAgri2015/Ol\% C3\%A9agineux_et_Ni\%C3\%A9b\%C3\%A9.pdf.

Ouedraogo, J.T., Sawadogo. M., Tignegre, J.B.,
DRABO, I., BALMA，D., 2010. Caractérisation agro-morphologique et moléculaire de cultivars locaux de niébé (Vigna unguiculata) du Burkina Faso. Cameroon J. Exp. Biol., 6(1): 31-40.

Sanginga, N., Dashiell, K.E., Diels, J., Vanlauwe, B., Lyasse, O., Carsky, R.J., Tarawali, S., Asafo, A.B., Menkir, A., Schulz, S., Singh, B.B., Chikoye, D., Keatinge, D., Ortiz, R., 2003. Sustainable resource management coupled to resilient germplasm to provide new intensive cereal-grain-legume livestock systems in the dry savanna. Agric. Ecosyst. Environ., 100: 305-314.

Stoilova, T., Pereira, G., 2013. Assessment of the genetic diversity in a germplasm collection of cowpea (Vigna unguiculata (L.) Walp.) using morphological traits. Afr. J. Agric. Res., 8(2): 208-215.

Taffouo, V.D., Ndongo, D.J., Nguelemeni, M.P., Eyambé, Y.M., Tayou, R.F., Akoa, A., 2008. Effets de la densité de semis sur la croissance, le rendement et les teneurs en composés organiques chez cinq variétés de niébé (Vigna unguiculata L. Walp). J. Appl. Biosci., 12: 623-632.

Tarawali, S.A., Singh, B.B., Gupta, S.C., Tabo, R., Harris, F., Nokoe, S., Fernández-Rivera, S., Bationo, A., Manyong, V.M., Makinde, K., Odion, E.C., 2002. Cowpea as a key factor for a new approach to integrated crop- livestock systems research in the dry savannas of West Africa. In: Fatokun, C.A., Tarawali, S.A., Singh, B.B., Kormawa, P.M., Tamo, M. (Eds.), Challenges and Opportunities for Enhancing Sustainable Cowpea Production. International Institute of Tropical Agriculture: Ibadan, Nigeria. pp. 233-251.

Yao, S.D.M., Koffi, E.B.Z., Daramcoum, W.A.M.P., Yoboue, K., Konan, J.L.K., Diarrassouba, N., Bourdeix, R., Sie, R.S., 2020. Apport des descripteurs qualitatifs dans l'identification des accessions de cocotier Grand pour les programmes de régénération des collections au champ. Int. J. Biol. Chem. Sci., 14(2): 580-599.

\section{How to cite this article:}

Assouman, J. S. K., Diarrassouba, N., Yao, S. D. M., 2021. Preliminary study on morphological diversity of cowpea accessions [Vigna unguiculata (L.) Walp.] collected in the North of Côte d'Ivoire. Int. J. Curr. Res. Biosci. Plant Biol., 8(9): 1-12. doi: https://doi.org/10.20546/ijcrbp.2021.809.001 